\title{
Assessment of Silica Recovery from Metallurgical Mining Waste, by Means of Column Flotation
}

\author{
Eleazar Salinas-Rodriguez ${ }^{1}{ }_{(\mathbb{D})}$, Javier Flores-Badillo ${ }^{1}$, Juan Hernandez-Avila ${ }^{1, *(D)}$, \\ Eduardo Cerecedo-Saenz ${ }^{1, * \mathbb{D}}$, Ma. del Pilar Gutierrez-Amador ${ }^{2}$, Ricardo I. Jeldres ${ }^{3}$ (D)
} and Normam Toro 4,5

1 Area Academica de Ciencias de la Tierra y Materiales, Universidad Autonoma del Estado de Hidalgo, Carretera Pachuca-Tulancingo km 4.5, Mineral de la Reforma, Hidalgo C.P. 42184, Mexico; salinasr@uaeh.edu.mx (E.S.-R.); jfb.cmat@gmail.com (J.F.-B.)

2 Escuela Superior de Apan, Universidad Autonoma del Estado de Hidalgo. Carr. Apan-Calpulalpan km. 8, Apan, Hidalgo C.P. 43920, Mexico; gutierrezam@yahoo.com

3 Departamento de Ingenieria Quimica y Procesos de Minerales, Facultad de Ingenieria, Universidad de Antofagasta, Antofagasta 1240000, Chile; ricardo.jeldres@uantof.cl

4 Departamento de Ingenieria Metalurgica y Minas, Universidad Catolica del Norte, Antofagasta 1270709, Chile; ntoro@ucn.cl

5 Department of Mining, Geological and Cartographic Department, Universidad Politecnica de Cartagena, 30202 Murcia, Spain

* Correspondence: herjuan@uaeh.edu.mx (J.H.-A.); mardenjazz@yahoo.com.mx (E.C.-S.); Tel.: +52-771-125-8798 (J.H.-A.); +52-771-195-6006 (E.C.-S.)

Received: 20 November 2019; Accepted: 27 December 2019; Published: 2 January 2020

check for updates

\begin{abstract}
The generation of mining waste commonly led to the use of spaces for its disposal. Challenges like mitigating the damage to surrounding communities have promoted the need to reuse, recycle and/or reduce their generation. Besides, these residues may become a source of materials, which are capable of being recovered and reused in several industries, minimizing the environmental impact. In the mining region of Pachuca, Mexico, waste from the mining industry have been generated for more than 100 years, which have a high $\mathrm{SiO}_{2}$ content that can be recovered for various industrial applications. This work aims to recover silica from a material of the Dos Carlos dam. A columnar system composed of two-stage of cleaning was used, considering a $J_{L T}$ (surface liquid rate) value of 0.45 and $0.68 \mathrm{~cm} / \mathrm{s}$, respectively; while the $J_{g}$ (surface gas rate) value was $0.30 \mathrm{~cm} / \mathrm{s}$ for both stages. Similar bubble sizes in the range of $J_{g} 0.10$ to $0.30 \mathrm{~cm} / \mathrm{s}$, with values between 0.14 and $0.16 \mathrm{~cm}$ in the first stage, and 0.05 to $0.06 \mathrm{~cm}$ in the second one. This provided a recovery of $75.10 \%$ for all the allotropic phases of silica (quartz, trydimite, and cristobalite) leaving a concentration of $24.90 \%$ of a feldspathic phase (orthoclase), as flotation tails.
\end{abstract}

Keywords: silica recovery; column flotation; mining waste; waste reprocessing

\section{Introduction}

Since the pre-Hispanic era to date, Mexico has been a mining country, and this activity has pointed more on precious metals ores. Particularly in the mining district of "Pachuca-Real del Monte" in the State of Hidalgo, the mineral processing has included several technologies ranging from the benefit of "Patio", froth flotation, and cyaniding, generating over 460 years of tailings that is deposited in four mining dams. "Dos Carlos" is one of the oldest [1]. The principal species found in this kind of residues is $\mathrm{Si}$ with content from $56 \%$ to $70 \%$, and the presence of $\mathrm{Ag}$ and $\mathrm{Au}$, which has given added value to these waste $[1,2]$. 
Due to the above pointed, some works have devoted to recovering the metallic values involved in these waste $[1,3,4]$, leading so a second residue with important amounts of $\mathrm{SiO}_{2}$ and feldspars, which could also be of commercial interest.

As was pointed, the "Dos Carlos" dam is one of the oldest in the Pachuca-Real del Monte Mining District, established since 1912. Consequently, this dam has an approximate amount of waste (coming from the processes of grinding, flotation and cyanidation) of more than 14.3 million tons [1]. These residues have a chemical composition corresponding to $70.43 \% \mathrm{SiO}_{2}, 7.32 \% \mathrm{Al}_{2} \mathrm{O}_{3}, 2.32 \% \mathrm{Na}_{2} \mathrm{O}$, $0.08 \% \mathrm{~K}_{2} \mathrm{O}, 0.69 \% \mathrm{CaO}, 0.54 \% \mathrm{MgO}, 0.73 \% \mathrm{MnO}, 2.80 \% \mathrm{Fe}_{2} \mathrm{O}_{3}, 2.41 \% \mathrm{FeO}, 0.53 \% \mathrm{TiO}_{2}, 0.12 \% \mathrm{P}_{2} \mathrm{O}_{5}$, $55 \mathrm{ppm}$ of $\mathrm{Ag}$, and $0.58 \mathrm{ppm}$ of $\mathrm{Au}[5,6]$. Similarly, the described residues show a coarse granulometry of the order of $60 \%$ accumulated up to the 270 mesh $(53 \mu \mathrm{m})$ [5].

These residues constitute an important source of materials that can be effectively reused, considering that the contents of silica and feldspars can be recovered; the silver and gold and finally the residual oxides. Therefore, the recovery and the obvious market for precious metals [7] results in direct profits, while the demand for silica and feldspars includes the ceramics, chemistry, glass, abrasives, silicate acid refractories, additives [8], and finally the oxides for the cement and glass industry.

Regarding the flotation of material from natural siliceous sand deposits, there are different methods and uses of reagents, depending on the impurities contained in the siliceous sand. For feldspathic sands with quartz, fatty acids are mainly used as collectors in a neutral or slightly basic medium during the primary phase of elimination of iron and titanium oxides. In the secondary stage, it is necessary the elimination of micas and feldspars, which is achieved from primary amine collectors in acid medium, by the addition of sulfuric acid. In addition, in the removal of feldspars, ammonium bifluorofuroide is used as a depressant agent, achieving that the silica law reaches $98 \%$ of purity, with minimum additions of the order of $0.97 \% \mathrm{Al}_{2} \mathrm{O}_{3}$ and $0.05 \% \mathrm{Fe}_{2} \mathrm{O}_{3}$ [9].

Moreover, the separation during the second phase is achieved by acidic $\mathrm{pH}$ of the order of 2 to 2.5 , using $\mathrm{H}_{2} \mathrm{SO}_{4}$ or failing with $\mathrm{HF}$, in a concentration of $2000-2500 \mathrm{ppm}$. The latter is also a depressant of the feldspathic portion, providing that the silica particle can be cleaned superficially from metal oxides; this modified process generated a silica content of $98.36 \%$ [10].

Besides, it is also possible to use cationic reagents based on complex sulfates, for the flotation of the silica from sands containing quartz and feldspar; by using silica activating agents such as $\mathrm{Ca}^{2+}$, $\mathrm{Ba}^{2+}$ and $\mathrm{Sr}^{2+}$, thus achieving an adequate flotation of the silica without the use of HF [11].

In a nutshell, the glass and chemical industries require a high standard of silica quality that means composition over $99.8 \%$, with impurities less than $0.02 \%$ of hematite and alumina, as well as values lower than $0.1 \%$ of lime and magnesia [12]. Nevertheless, comparing with the previous investigations, the silica recoveries are still far from the amount expected to place it in the industries mentioned above.

Since flotation is a process widely used for mineral concentration, the study of size and quantity of bubbles, the particle sizes and hydrophobic conditions, and many other factors are of great importance [13]. According to this, mineral extraction from tailing is a technological challenge in mining and metallurgical operations. It needs an in-depth study of technical and economic feasibility [14], being the flotation an adequate technique for the concentration and recovery of minerals from ores and waste. The flotation in column also represents an appropriate option for the recovery and or concentration of minerals, where the model studied is related to a stable state behavior, taking in account variables such as dynamic mass balance, type of pulp, markers, bubble distribution and flux, bubble size, cations effect, and bubble coalescence, among others [15-17].

In this context, the principal aim of this work is to recover silica by column flotation, using the tailings form the "Dos Carlos" dam. This proposal offers significant advantages since it reuses a material considered waste. Thus it will be given a higher value, and unlike the processes used commercially, as described in previous paragraphs, it will be more advantageous and viable. 


\section{Materials and Methods}

Firstly, the material used in this work was waste coming from the mining industry of the mining district of Pachuca-Real del Monte, which was sampled selectively at the "Dos Carlos" dam, using the channel technique. The sample so collected was homogenized by quartering and then characterized to disclose the mineral species involved and its chemical composition. The whole characterization was carried out by X-ray diffraction (XRD), using an Equinox 2000 diffractometer (INEL, Artenay, France) with $\operatorname{CoK} \alpha_{1}$ radiation $(\lambda=1.78901 \AA)$, at $30 \mathrm{kV}, 20 \mathrm{~mA}$ and a scanning speed of $22 \theta / \mathrm{min}$. Phase identification was based on the COD Inorganics 2015 and Cements 2014 databases included in the Crystallography Open Database; Match! software used in this procedure (v.1.10, Crystal Impact, Bonn, Germany).

In addition, the shape and size of waste particles were determined by a scanning electron microscopy, in conjunction with energy dispersive spectrometry of X-Rays (SEM-EDS). In this case was used a JEOL scanning electron microscope, model JSM-IT300 (JEOL Ltd., Tokyo, Japan) which has an OXFORD X-ray detector (OXFORD Instruments, Oxfordshire, UK), employing an acceleration voltage of $30 \mathrm{kV}$.

Secondly, the chemical determination was executed by atomic absorption spectroscopy (AAS) using a spectrophotometer Perkin Elmer model 2380. In addition, X-ray fluorescence (XRF) chemical analysis was run by a SIEMENS spectrophotometer belonging to the ceramic company Morgan SA of $\mathrm{CV}$, located in Pachuca, Mexico. Samples were mixed with lithium hexaborate in a 5:1 ratio and then fused in a furnace at $1473 \mathrm{~K}$ to obtain a button, which was irradiated with an Rh anticathode using the following crystals for their evaluation; LiF200, Ge111, and T1AP. Calibration was done using different oxides of known composition.

On the other hand, the recovery of the silica was carried out in a flotation column with two cleaning stages (Figure 1), using a concentration of $3 \%$ solids, and $50 \mathrm{ppm}$ of analytical grade dodecylamine of the brand Sigma-Aldrich $\left(\mathrm{C}_{12} \mathrm{H}_{25}-\mathrm{NH}_{2}\right)$. The frother reagent was methyl isobutylcarbonyl or MIBC in a concentration of $60 \mathrm{ppm}$ (Alkemin), adjusting to a $J_{g}$ value of $0.3 \mathrm{~cm} / \mathrm{s}$, a $J_{L T}$ of 0.45 and $0.68 \mathrm{~cm} / \mathrm{s}$, respectively, and without the addition of any depressant.

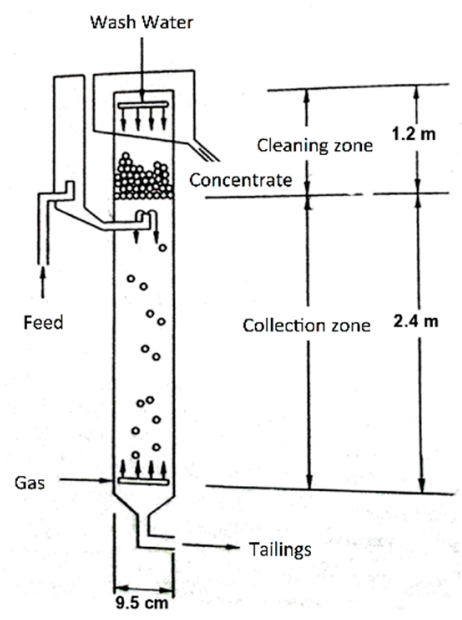

Figure 1. Schematic representation of the flotation column used in this study.

The respective values of $\varepsilon_{g}$ (retained gas), $D_{b}$ (particle size), and $S_{b}$ (surface bubble rate) were determined from the experiments; taking samples in each $J_{g}$ value, in the feed streams, tails and concentrate.

Finally, the concentrates resulting from the batch tests were characterized by XRD. The samples were sieved to obtain sizes between 74 and $53 \mu \mathrm{m}$ (Tyler ${ }^{\circledR} 200$ and 270 series meshes, respectively). Once this range of sizes was obtained, $1 \mathrm{~g}$ of sample was weighed and compacted in an aluminum sample holder for further analysis by XRD, determining the mineral phases present. 


\section{Results}

The results obtained by SEM-EDS are shown in Figure 2, where can be seen the general morphology of samples (Saning Electron Microscopy-Secondary Electrons (SEM-SE)) and its punctual composition obtained by EDS (a) before flotation stage, and (b) after flotation process. It can be noted that after the flotation of material, the residue resting has been enriched with $\mathrm{SiO}_{2}$.

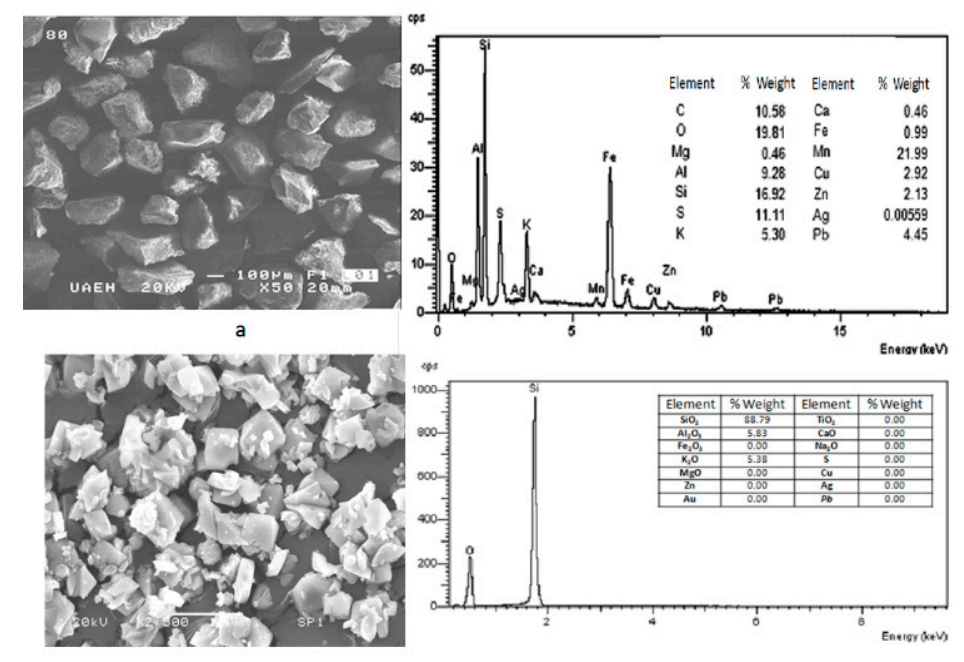

b

Figure 2. SEM-SE images and energy dispersive spectrometry (EDS) analysis executed on waste;

(a) before flotation, and (b) after flotation process.

In the case of the X-ray fluorescence, the obtained results are shown in Table 1. It is appreciated that the dominant species contained were silica, alumina, hematite, and potassium oxide, having also minor species such as magnesium oxide, calcium oxide, lead, zinc copper, silver, and gold.

Table 1. X-ray fluorescence (XRF) chemical analysis of material used for the flotation of silica.

\begin{tabular}{ccc}
\hline Element & Waste Prior Flotation $\%$ & Waste after Flotation $\%$ \\
\hline $\mathrm{SiO}_{2}$ & 73.3 & 91.2 \\
$\mathrm{Al}_{2} \mathrm{O}_{3}$ & 6.5 & 4.6 \\
$\mathrm{Fe}_{2} \mathrm{O}_{3}$ & 2.8 & 0.0 \\
$\mathrm{MgO}$ & 0.6 & 0.0 \\
$\mathrm{MnO}$ & 0.7 & 0.0 \\
$\mathrm{CaO}$ & 0.7 & 0.0 \\
$\mathrm{Na}_{2} \mathrm{O}$ & 0.08 & 0.0 \\
$\mathrm{~K}_{2} \mathrm{O}$ & 0.08 & 4.2 \\
$\mathrm{P}_{2} \mathrm{O}_{5}$ & 0.1 & 0.0 \\
$\mathrm{SO}_{3}$ & 0.9 & 0.0 \\
$\mathrm{ZnO}$ & 0.05 & 0.0 \\
$\mathrm{Ag}$ & $51(\mathrm{ppm})$ & 0.0 \\
$\mathrm{Au}$ & $0.6(\mathrm{ppm})$ & 0.0 \\
\hline
\end{tabular}

Figure 3 (1st stage line) displays the gas retained in the columnar flotation system, for the recovery in the batch system during the first stage of cleaning, with a flow of liquid in the stream of tails $\left(J_{L T}\right)$ of $0.45 \mathrm{~cm} / \mathrm{s}$, and applying a gas flow $\left(J_{g}\right)$ of $0.3 \mathrm{~cm} / \mathrm{s}$. Additionally, the lowest concentration of gas retained appeared in the central area of the column (manometers 2 and 3), because in this zone, the bubble pack had a higher rate of ascent. On the other hand, in the upper part of the column, an increase of gas retained in the system was observed, with a value of $3.3 \%$, decreasing the rising speed of the bubble package. The percentage of global retained gas was $2.3 \%$. 


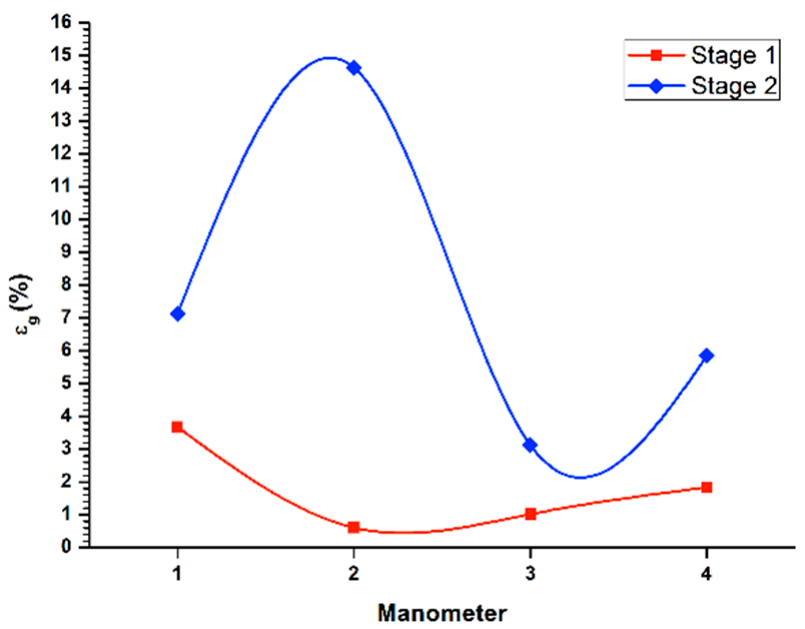

Figure 3. Determination of $\varepsilon_{g}$, in the bath flotation column of the material of the "Dos Carlos" dam, for $J_{I T}$ of $0.446,50$ ppm of $\mathrm{C}_{12} \mathrm{H}_{25} \mathrm{NH}_{2}$ as collector, and $60 \mathrm{ppm}$ of MIBC as foaming agent.

Likewise, same Figure 3 (2nd stage line) shows the determination of retained gas $\left(\varepsilon_{g}\right)$ in the columnar flotation system, for the recovery in batch system during the second cleaning stage, with a flow of liquid in the queuing stream $\left(J_{L T}\right)$ of $0.45 \mathrm{~cm} / \mathrm{s}$, applying the gas flow $\left(J_{g}\right)$ of $0.3 \mathrm{~cm} / \mathrm{s}$. In the central zone of the column (manometers 2 and 3), the highest concentration of gas retained in the system was presented, where the bubble packing has a lower acceleration. Besides, the values of gas retained at the ends of the column were similar at the top, which were slightly higher. The global percentage of gas retained was set at $15.2 \%$.

Similarly, Figure 4 shows the bubble size $\left(D_{b}\right)$ generated in the disperser, for the recovery in a batch system, with a flow of liquid in the tail stream $\left(J_{L T}\right)$ of $0.45 \mathrm{~cm} / \mathrm{s}$, applying the gas flow $\left(J_{g}\right)$ of $0.3 \mathrm{~cm} / \mathrm{s}$. The bubble size decreased between the two cleaning stages, thus generating an increase in gas retained in the system, as well as an increase in the superficial flow of bubbles. This, in turn, decreases the rising speed of the bubble pack, causing a lower recovery in the second stage.

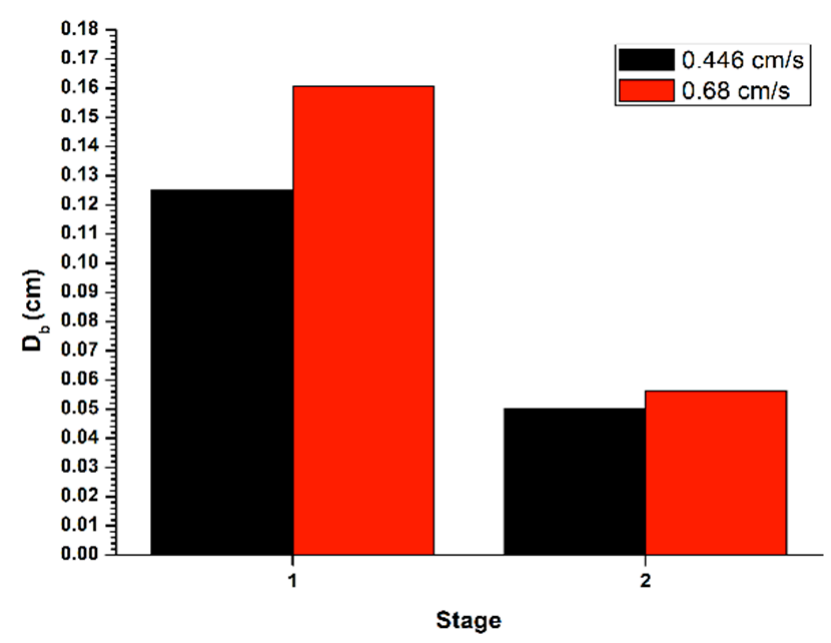

Figure 4. Determination of $D_{b}$ in the batch flotation column of the material of the Dos Carlos dam, for $J_{l T}$ of $0.446 \& J_{l T}$ of $0.68 \mathrm{~cm} / \mathrm{s}, 50 \mathrm{ppm} \mathrm{C}_{12} \mathrm{H}_{25} \mathrm{NH}_{2}$ as a collector, and $60 \mathrm{ppm}$ MIBC as foaming agent.

In the same Figure 4, it is shown the determination of the bubble size $\left(D_{b}\right)$ formed in the disperser, for the recovery in a batch system, with a flow in the tail stream $\left(J_{L T}\right)$ of $0.68 \mathrm{~cm} / \mathrm{s}$, applying the flow of gas $\left(J_{g}\right)$ of $0.3 \mathrm{~cm} / \mathrm{s}$. The bubble size decreased among the two cleaning stages, thus causing an increase 
in gas retained in system, as well as an increment in the superficial flow of bubbles. This caused a reduction in the bubble rising and hence a lower recovery in the second stage.

Figure 5 (1st stage line) shows the determination of gas retained in the columnar flotation cell, for the recovery in a batch system through the first cleaning stage, with a flow of liquid in the tail flow $\left(J_{L T}\right)$ of $0.68 \mathrm{~cm} / \mathrm{s}$, applying the gas flow $\left(J_{g}\right)$ of $0.3 \mathrm{~cm} / \mathrm{s}$. There was a higher concentration of gas retained in the lower part of the system (manometers 1 and 2), thus creating a low ascent velocity of the bubble pack. Likewise, the middle and upper parts, presented an increase in the speed of ascent of the bubble pack, the middle section being the fastest rise. This makes the bubble pack disperse, increasing the possibility of recovery. Regarding the global retained gas, a value of $1.84 \%$ was found, generally giving a higher ascent rate, although with a low bubble concentration that recovered the mineral and with other bubbles of considerable size.

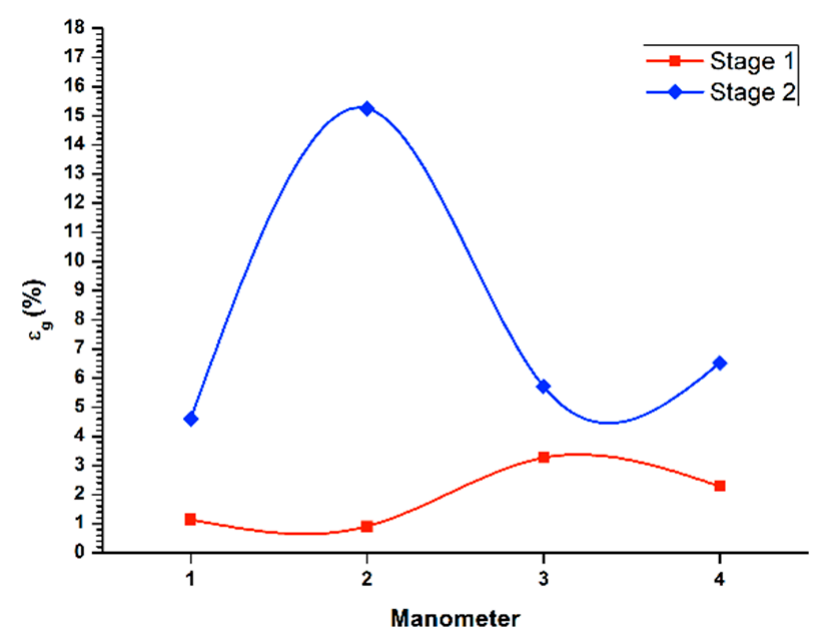

Figure 5. Determination of $\varepsilon_{g}$, in the bath flotation column of the material of the "Dos Carlos" dam, for $J_{I T}$ of $0.68,50 \mathrm{ppm}$ of $\mathrm{C}_{12} \mathrm{H}_{25} \mathrm{NH}_{2}$ as collector and $60 \mathrm{ppm}$ of MIBC as foaming agent.

Similarly, Figure 5 (stage 2 line) illustrates the determination of retained gas $\left(\varepsilon_{g}\right)$ in the columnar flotation system, for the recovery in the batch system during the second cleaning stage, with a flow of liquid in the tail stream $\left(J_{L T}\right)$ of $0.68 \mathrm{~cm} / \mathrm{s}$, applying the gas flow $\left(J_{g}\right)$ of $0.3 \mathrm{~cm} / \mathrm{s}$. In the middle zone of the flotation column (manometers 2 and 3), there was an increase in the concentration of the retained gas. This decelerated the ascent speed, and the recovery decreased, overloading the surface of the bubble with mineral. On the other hand, at the end of the flotation column, low concentrations of retained gas were present, and, therefore, higher rising rates of the bubble package. This result was more evident in the upper part of the column. Concerning global retained gas, a value of $5.9 \%$ is shown.

Figure 6 (stage 1) shows the determination of the bubble surface flow $\left(S_{b}\right)$ from $\varepsilon_{g}$ and $D_{b}$, for the recovery in batch system, with a flow of liquid in the tail stream $\left(J_{L T}\right)$ of $0.45 \mathrm{~cm} / \mathrm{s}$, applying the gas flow $\left(J_{g}\right)$ of $0.3 \mathrm{~cm} / \mathrm{s}$. The bubble surface flow increased between the two cleaning stages, thus generating an increase in gas retained in the system. Such effect was provided by a decrease in the initial bubble size from the first stage to a final one, in the second stage. Moreover, in Figure 6 (stage 2) is exposed the determination of the bubble surface flow $\left(S_{b}\right)$ from $\varepsilon_{g}$ and $D_{b}$, for the recovery in a batch system, with a flow in the stream of tails $\left(J_{L T}\right)$ of $0.68 \mathrm{~cm} / \mathrm{s}$, applying the gas flow $\left(J_{g}\right)$ of $0.3 \mathrm{~cm} / \mathrm{s}$. The bubble surface flow increased within the two cleaning stages, thus causing an increase in gas retained in the system. Such effect was provided by a decrease in the initial bubble size from the first stage to a final one, in the second stage. This, in turn, caused a reduction in the rising rate the bubble pack and, accordingly, a lower recovery in the second stage. 


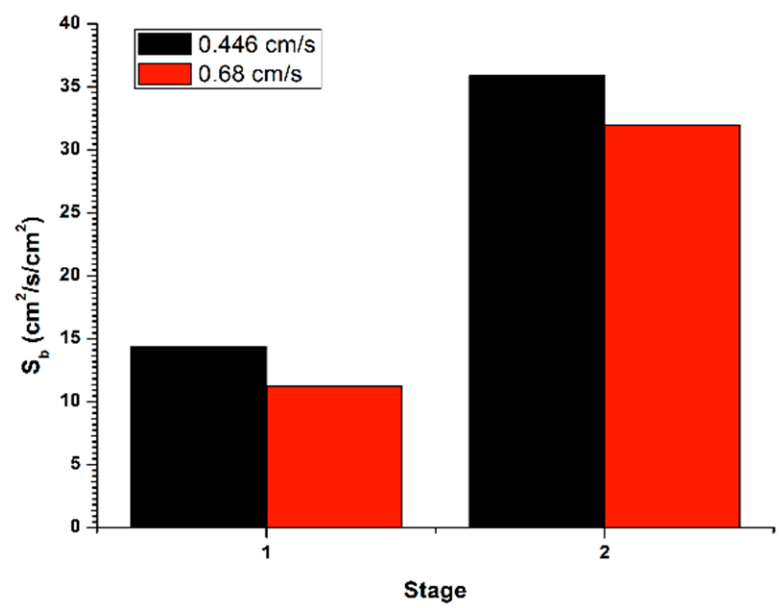

Figure 6. Determination of $S_{b}$ in the batch flotation column of the material of the Dos Carlos dam, for $J_{l T}$ of $0.446 \& J_{l T}$ of $0.68 \mathrm{~cm} / \mathrm{s}, 50 \mathrm{ppm} \mathrm{C}{ }_{12} \mathrm{H}_{25} \mathrm{NH}_{2}$, as a collector and $60 \mathrm{ppm} \mathrm{MIBC}$ as foaming agent.

Figure 7a illustrate the X-ray diffractogram corresponding to the first flotation stage at a $J_{L T}=0.446 \mathrm{~cm} / \mathrm{s}$. The major phases are Quartz, Orthoclase, and Tridymite, being the Cristobalite the remaining phase.

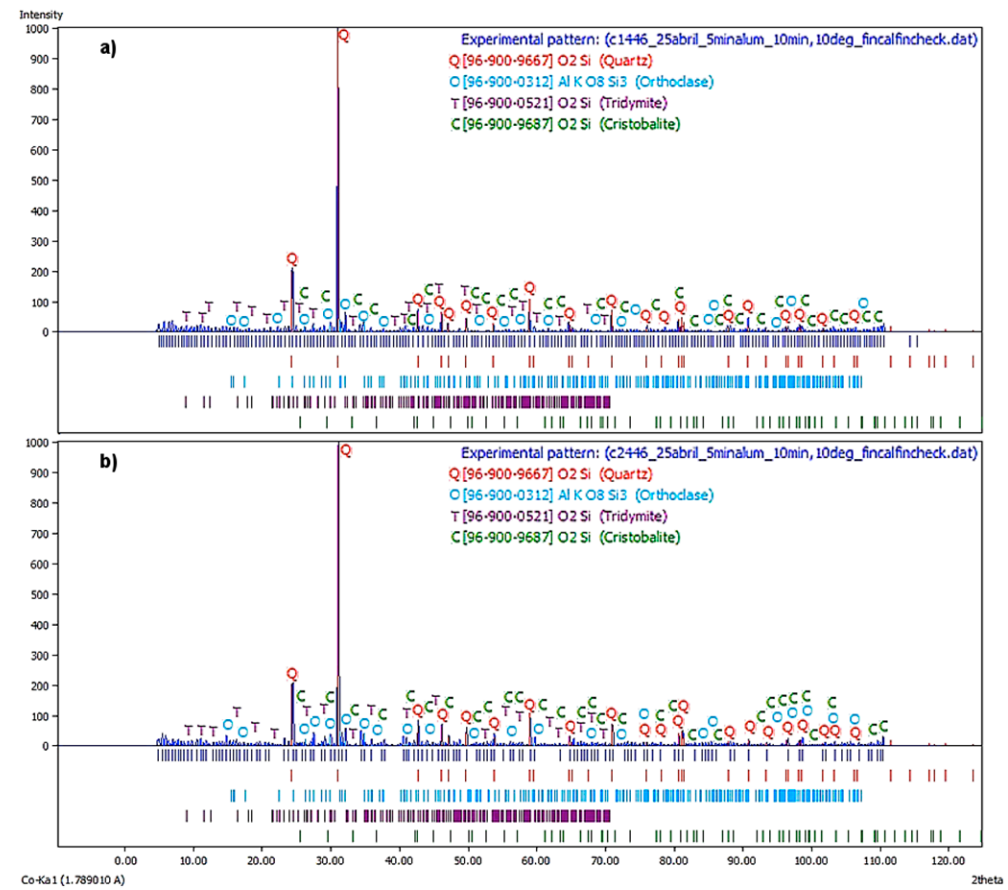

Figure 7. X-ray diffractogram of the material of the "Dos Carlos" dam recovered from the (a) first flotation stage at $J_{l T}=0.47 \& \mathrm{~cm} / \mathrm{s}$, and (b) second stage of flotation at $J_{l T}=0.45 \mathrm{~cm} / \mathrm{s}$.

In Figure $7 \mathrm{~b}$, the X-ray diffractogram corresponds to the second flotation stage at a $J_{L T}=0.45 \mathrm{~cm} / \mathrm{s}$. It is observed that the principal phases were quartz, orthoclase, and tridymite. The cristobalite was a remaining phase. This spectrum displayed similar behavior to the previous.

On the other hand, Figure 8a shows the X-ray diffractogram corresponding to the first flotation stage at a $J_{L T}=0.68 \mathrm{~cm} / \mathrm{s}$. The principal phases were quartz, orthoclase, and berlinite, where the albite was the remaining phase. Note that due to an increase in liquid flow rates, there were more feldspathic phases and a phase analogous to quartz, although the major one was still quartz, concerning the same stage and at a $J_{L T}=0.47 \mathrm{~cm} / \mathrm{s}$. 


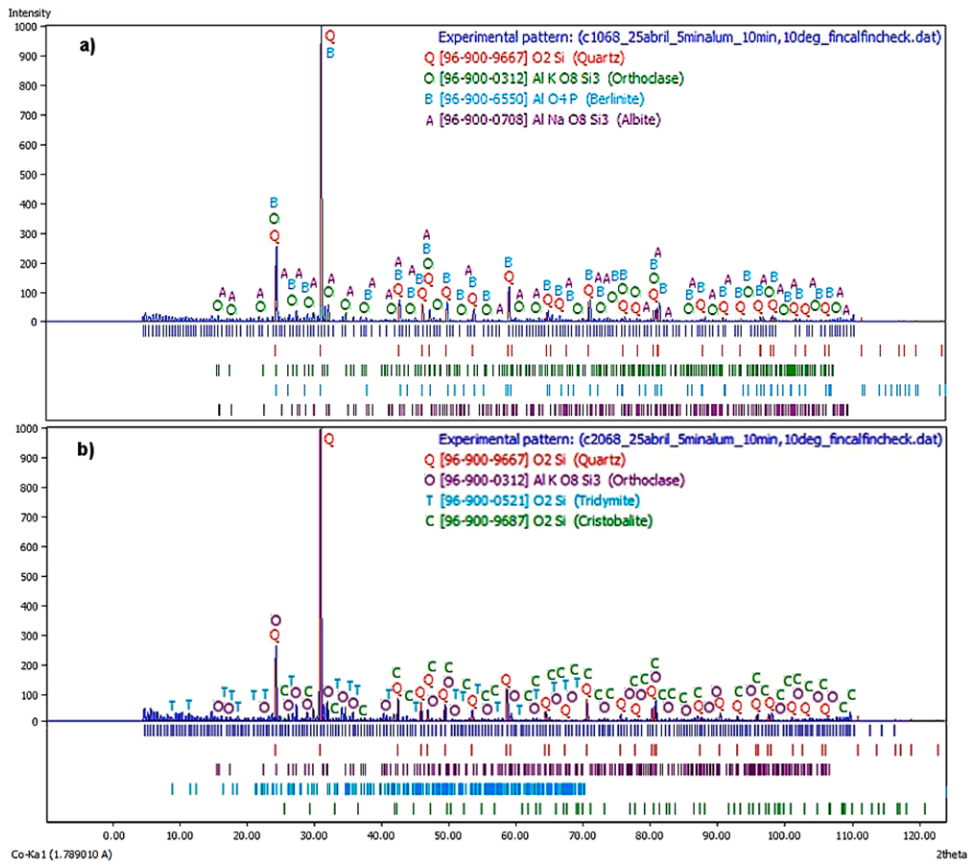

Figure 8. X-ray diffractogram of the material of the "Dos Carlos" dam recovered from the (a). First flotation stage at $J_{l T}=0.68 \mathrm{~cm} / \mathrm{s}$, and (b). Second stage of flotation at $J_{l T}=0.68 \mathrm{~cm} / \mathrm{s}$.

Figure $8 \mathrm{~B}$ shows the $\mathrm{X}$-ray diffractogram corresponding to the second flotation stage at a $J_{L T}=0.45 \mathrm{~cm} / \mathrm{s}$. It is observed that the major phases were quartz, orthoclase, and tridymite, while cristobalite was the remaining phase. The behavior was similar to the two stages of the batch process $J_{L T}=0.45 \mathrm{~cm} / \mathrm{s}$.

Regarding the percentages by weight of each phase, it is recognized in Table 2 that at a lower liquid velocity, a higher concentration of quartz was present. In the second stage at a $J_{L T}=0.68 \mathrm{~cm} / \mathrm{s}$, there was an increase in the level of quartz and orthoclase, cristobalite and tridymite also appearing. This might have happened due to the elimination of albite and berlinite. For flotation at lower liquid velocity, as well as a value of $J_{L T}=0.45 \mathrm{~cm} / \mathrm{s}$, a similar behavior was found between the two stages, since it increased the concentration of allotropic phases of the silica, decreasing the concentration of orthoclase.

Table 2. Present phases and their percentage in weight, obtained in the two stages of batch flotation, at values of $J_{L T}=0.68$ and $0.45 \mathrm{~cm} / \mathrm{s}$, respectively. The phases were obtained by means of XRD.

\begin{tabular}{ccccccc}
\hline \multirow{2}{*}{ Entry Number } & \multirow{2}{*}{ Phase } & Formula & \multicolumn{2}{c}{$\begin{array}{c}\text { Flotation } \\
J_{\boldsymbol{L T}}=\mathbf{0 . 6 8} \mathbf{~ c m} / \mathbf{s}\end{array}$} & \multicolumn{2}{c}{$\begin{array}{c}\text { Flotation } \\
\boldsymbol{J}_{\boldsymbol{L T}}=\mathbf{0 . 4 5} \mathbf{~ c m} / \mathbf{s}\end{array}$} \\
\cline { 4 - 6 } & & & 1st Stage & 2nd Stage & 1st Stage & 2nd Stage \\
\hline $96-900-9667$ & Quartz & $\mathrm{SiO}_{2}$ & $56.5 \%$ & $61.2 \%$ & $69.9 \%$ & $69.6 \%$ \\
$96-900-9687$ & Cristobalite & $\mathrm{SiO}_{2}$ & $0.0 \%$ & $1.6 \%$ & $0.8 \%$ & $1.6 \%$ \\
$96-900-0521$ & Tridymite & $\mathrm{SiO}_{2}$ & $0.0 \%$ & $7.6 \%$ & $3.5 \%$ & $3.9 \%$ \\
$96-900-0312$ & Orthoclase & $\mathrm{KAlSi}_{3} \mathrm{O}_{8}$ & $27.2 \%$ & $29.6 \%$ & $31.8 \%$ & $24.9 \%$ \\
$96-900-0707$ & Albite & $\mathrm{NaAlSi}_{3} \mathrm{O}_{8}$ & $2.7 \%$ & $0.0 \%$ & $0.0 \%$ & $0.0 \%$ \\
$96-900-6550$ & Berlinite & $\mathrm{AlPO}_{4}$ & $13.6 \%$ & $0.0 \%$ & $0.0 \%$ & $0.0 \%$ \\
\hline
\end{tabular}

\section{Discussion}

In this work, a flotation column was used for the separation of silica and feldspars from mining waste, since flotation columns have advantages over conventional cells [18], because they do not use mechanical agitation, they operate with bubbles much smaller than common cells, and with long residence times, an improvement in the degree of recovery is achieved. Similarly, another additional 
advantage is that flotation columns can treat a large volume of ore, occupying a small area, as well as very fine minerals, at very attractive investment and operation costs $[19,20]$.

Consequently, the main disadvantage of the flotation columns lies in their low capacity to recover thick particles [21], but this is not the case where there is a fine grain size.

Therefore, the use of flotation columns for the recovery of silica and feldspar, offers many advantages, especially in the improvement in grade and recovery for an isochemical mineral like the one studied here.

Due to the need of understanding what happens during quartz flotation, precious studies related to this topic using DDA, showed that flotation radically decrease with sizes from hydrophobic aggregate, which in turn increases with the length of the collector chain [22]. Similarly, flotation depends more significant on particle and bubble sizes. For instance, when there are small bubbles, high flotation rates can be reached at very low power intensities. On the other hand, when larger bubbles are present, flotation rate increases with increasing of the surface area's intensity, when both fine and intermediate particle sizes are treated. In addition, an optimal intensity of power was reached for thicker particles, just as is the case found in this work [23]. In the same way, flotation was not affected by the particle size, although we did the study with fine and thick particle sizes.

For $\mathrm{SiO}_{2}$ flotation, the influence of ions (type, concentration, and their combination) on the bubble coalescence disclosed that the hydrophobic attraction was reduced with the increase of collector concentration. Due to the decrease in the solubility of the gas phase, the change of the superficial tension and the rheology of the thin liquid film in the gas-water and ion-water interfaces, depending on the hydrodynamic condition (static condition) [16]. In the case of this study, a low concentration of retained gas was generated. Therefore, a continuous recovery was obtained, due to the existence of a good flux rate, which was generated for the bubble pack, and also due to the minimum concentration of sulphur species and the $\mathrm{Fe}_{2} \mathrm{O}_{3}$, when using $\mathrm{C}_{12} \mathrm{H}_{25} \mathrm{NH}_{2}$ as collector, because at low values of $J_{g}$, especially $0.3 \mathrm{~cm} / \mathrm{s}$, a concentration of $81.66 \%$ was reached joint to a decrease to zero concentration of $\mathrm{Fe}_{2} \mathrm{O}_{3}$.

Similarly, some researchers [24] did conventional flotation experiments with a mixture of feldspars and quartz in diluted solutions of hydrofluoric acid (HF), obtaining important recoveries for quartz (95.4\% quartz recovery with a global recovery of $88.6 \%$ ), and a concentration of feldspar of $99.9 \%$ (95.9\% for albite and 95.5 for microcline). In this work during the batch flotation in column a $75.13 \%$ of recovery was reached for all the allotropic phases of silica (quartz, tridymite and cristobalite), and of $24.87 \%$ of a feldspathic phase (orthoclase), which is favourable to environment because there is no use of acids, activators and depressants, combined with a low concentration of collecting agents and foaming agents.

Consequently, as is shown in this work, this new concept could be used to produce a quartz concentrate, which also could be of great value as an important stage of cleaning to remove the last remnants of feldspars from the product. In the same way, this process has also probed for recycling porpoises. Some researches [14] have pointed that the used model for the flotation, are efficient for this kind of processes used for iron minerals waste. Larsen and Kleiv [24], found that silica was recovered quite successfully from a slag coming from the production of silicon in an electric reduction smelting furnace.

\section{Conclusions}

In the medium dodecylamine $\left(\mathrm{C}_{12} \mathrm{H}_{25}-\mathrm{NH}_{2}\right)$, it was studied the recovery of silica from the waste of the "Dos Carlos" dam, in a batch flotation system with two cleaning stages. The experimental condition considered $J_{g}$ of $0.3 \mathrm{~cm} / \mathrm{s}$, in both cleaning stages, and $J_{L T}$ of 0.45 and $0.68 \mathrm{~cm} / \mathrm{s}$, for each one. Similar bubble sizes were obtained for the range of $J_{g} 0.1$ to $0.3 \mathrm{~cm} / \mathrm{s}$ of the effect of JL, generating a similar retained gas concentration and therefore promoting a steady recovery, since there was a comparable rising speed of the bubble pack. 
In the characterization by $\mathrm{XRD}$, a particular phenomenon was presented since at a lower surface velocity of the liquid and especially at a $J_{L T}$ value of $0.45 \mathrm{~cm} / \mathrm{s}$, an area of the higher collection was introduced in the lower half of the column. So in the batch column flotation, consisting of two stages, $75.13 \%$ of recovery was achieved for all the allotropic phases of the silica (quartz, tridymite and cristobalite). This leaves a concentration of $24.87 \%$ of a feldspathic phase (orthoclase) as a remnant. Finally, according the obtained results, we can propose the use of the silica obtained in the cement industry, principally.

Feldspar residue with varying amounts of calcium, potassium or sodium $[25,26]$, has a low melting point $758 \mathrm{~K}\left(485^{\circ} \mathrm{C}\right)$, and it is used in the manufacture of glass, since alumina gives it hardness, durability and resistance to chemical corrosion. The second use of feldspar is in the ceramic industry, where its use as a flux for ceramic vitrification. Similarly, it is known that according to the content of potassium, the greater the amount of it, the material has a better performance as a cementing agent [27].

The advantage of using feldspar obtained as a byproduct of an epithermal reservoir like the one studied here, offers advantages over one of residual origin; since feldspar of isochemical primary origin is a pure material [25]. Additionally, the bounded particle size is of importance for the ceramic industry, because the ideal size should be greater than 170-200 meshes (74-88 microns), according to the US Geological Survey [27,28]. For this case, the waste material recovered here, exceeds 170 meshes (88 microns), and due to the comminution of the waste is more competent, mechanically. Likewise, due to surface exposure, the secondary feldspar usually has hematite alterations that affect the color of the ceramics and the flux function is modified because the iron is high temperature.

Consequently, recovered feldspars can be considered mixed because of their sodium, potassium and calcium contents. Therefore, its use could be in the elaboration of construction material (tiles, decoration material), abrasives (sandpaper for wood), seed coating, scrubbing soaps. However, this feldspar could be used in white paste and fine porcelain ceramics, but a second flotation would have to be done to remove residual impurities such as iron, since a maximum of $1 \% \mathrm{Fe}$ is required for this use.

On the other hand, quartz, tridymite, and cristobalite, since they are of primary origin, are usually isochemicals of greater purity, unlike the supergenic quartz of areas of residual sand, due to the great variety of quartz components that are the result of their secondary alteration, such as el, jasper, chalcedony, chert, opal, or other siliceous varieties. This is due to the fact that the chemistry of supergenic quartz is varied and depends essentially on the type of rock affected. Industrial sand and gravel, often called "silica," "silica sand," and "quartz sand," include sands and gravels that are high in silicon dioxide $\left(\mathrm{SiO}_{2}\right)$. These arenas are used in the manufacture of glass; for hydraulic fracture, fracture, and abrasive applications, mainly.

The chemical composition and physical properties of the silica recovered from the "Dos Carlos" dam, show that it can be used as a raw material for the ceramic industry. Similarly, it can also be an alternative for the cement industry because of its silica content [29], and for the manufacture of building materials, as well as a substitute for mixed feldspars, in some common applications and uses.

Similarly, silica sand is used as a granular filter medium in the treatment of drinking and wastewater. Because of its hardness, it can be used in the manufacture of sandpaper, industrial abrasives, and blasting sand, in formulas of detergents, paints, concrete, and special mortars, in addition to being the basis for the manufacture of refractories based on silica [30-33].

Author Contributions: E.S.-R., J.H.-A., and E.C.-S. contributed in the conceptualization and develop of methodology, J.F.-B. contributed in methodology and data curing, M.d.P.G.-A. contributing in analysis of data, R.I.J. and N.T. contributed resources and review, J.F.-B. and E.S.-R. contributing in wrote paper, R.I.J. and N.T. contributing in funding acquisition for publishing fees. All authors have read and agreed to the published version of the manuscript.

Funding: This research received no external funding for experimental and analytical work.

Acknowledgments: Authors thank to the PRODEP-SEP for the financial support granted in the publication of this paper. Also thanks go to the UAEH for the technical support given for the realization of this work.

Conflicts of Interest: The authors declare no conflict of interest. 


\section{References}

1. Salinas-Rodríguez, E.; Hernández-Ávila, J.; Cerecedo-Sáenz, E.; Arenas-Flores, A.; Reyes-Valderrama, M.I.; Roldán-Contreras, E.; Rodríguez-Lugo, V. Leaching of Silver Contained in Mining Tailings: A Comparative Study of Several Leaching Reagents. In Silver Recovery from Assorted Spent Sources: Toxicology of Silver Ions; Syeb, S., Ed.; King Saudi University: Riyadh, Saudi Arabia, 2018.

2. Geyne, A.R.; Fries, C. Geology and mineral deposits of the Pachuca-Real del Monte district, State of Hidalgo. In Consejo de Recursos Minerales no Renovables; Real del Monte y Pachuca Mining Company: Pachuca, México, 1963.

3. Hernández, A.J.; Rivera, L.I.; Patiño, C.F.; Juárez, T.J. Characterization and kinetics of the grinding of the Dos Carlos burrows in the State of Hidalgo. In Proceedings of the 31st Annual Conference of the International Precious Metals Institute 2007 and Petroleum Refining Seminar, Miami, FL, USA, 9-12 June 2007.

4. Salinas, R.E.; Patiño, C.F.; Hernández, A.J.; Hernández, C.L.; Rivera, L.I. La problemática de los Jales en el Estado de Hidalgo; V Congreso Nacional de Metalurgia y Materiales: Monclova, México, 2006; pp. 237-328. (In Spanish)

5. $\quad$ Flores, B.J.; Hernández, A.J.; Salinas, R.E.; Pérez, L.M.; Rivera, L.I.; Mireles, G.I.; Cerecedo, S.E. Preparation of blocks from tailings. In Engineering Solutions for Sustainability. Materials and Resources II, 1st ed.; Jeffrey, W.F., Brajendra, M., Dayan, A., Emily, A.S., Neale, R.N., Eds.; Wiley and Sons/TMS: Orlando, FL, USA, 2015; Volume 1, pp. 127-134. ISBN 978-1-119-17984-9.

6. Salinas, R.E.; Flores, B.J.; Hernández, A.J.; Vargas, R.M.; Flores, H.J.A.; Rodríguez, L.V.; Cerecedo, S.E. Design and production of a new constriction material (Bricks) using mining tailings. J. Eng. Sci. Res. Technol. 2017, 6, 225-238. [CrossRef]

7. Salinas-Rodríguez, E.; Hernández-Ávila, J.; Rivera-Landero, I.; Cerecedo-Sáenz, E.; Reyes-Valderrama, M.I.; Correa-Cruz, M.; Rubio-Mihi, D. Leaching of silver contained in mining tailings, using sodium thiosulfate: A kinetic study. Hydrometallurgy 2016, 160, 6-11. [CrossRef]

8. Galán, E.; Aparicio, P. Materias primas para la industria ceramic. In Seminarios de la Sociedad Española de Mineralogía, 1st ed.; Universidad de Alicante \& Sociedad Española de Mineralogia: Alicante, Spain, 2006; Volume 2, pp. 31-48. (In Spanish)

9. Klyachin, V.V.; Stepanova, M.V. Production of high-quality quartz concentrate from quartz-feldspar sands. Glas. Ceram. 1982, 39, 515-516. [CrossRef]

10. Klyachin, V.V. The selective flotation of quartz? feldspar sands by a new method. Glas. Ceram. 1969, 26, 174-176. [CrossRef]

11. El-Salmawy, M.; Nakahiro, Y.; Wakamatsu, T. The role of alkaline earth cations in flotation separation of quartz from feldspar. Miner. Eng. 1993, 6, 1231-1243. [CrossRef]

12. Stulov, A. (Universidad de Concepción, Instituto de Investigaciones Tecnológicas, Concepción, Región del Bío Bío, Chile). Personal communication, 1963.

13. Alvarez-Silva, M.; Vinnett, L.; Langlois, R.; Waters, K. A comparison of the predictability of batch flotation kinetic models. Miner. Eng. 2016, 99, 142-150. [CrossRef]

14. Büttner, P.; Osbahr, I.; Zimmermann, R.; Leißner, T.; Satge, L.; Gutzmer, J. Recovery potential of flotation tailings assessed by spatial modelling of automated mineralogy data. Miner. Eng. 2018, 116, 143-151. [CrossRef]

15. Bouchard, J.; Desbiens, A.; Del Villar, R. Column flotation simulation: A dynamic framework. Miner. Eng. 2014, 55, 30-41. [CrossRef]

16. Yianatos, J.; Vinnett, L.; Panire, I.; Alvarez-Silva, M.; Díaz, F. Residence time distribution measurements and modelling in industrial flotation columns. Miner. Eng. 2017, 110, 139-144. [CrossRef]

17. Filippov, L.O.; Javor, Z.; Piriou, P.; Filippova, I.V. Salt effect on gas dispersion in flotation column-Bubble size as a fucntion of turbulent intensity. Miner. Eng. 2018, 127, 6-14. [CrossRef]

18. Bergh, L.; Yianatos, J. Control alternatives for flotation columns. Miner. Eng. 1993, 6, 631-642. [CrossRef]

19. Suárez, C.G.A.; García, R.E.; Amariz, B.J.J.J. Column flotation as technique for the benefit of fine minerals. Tecnura 2005, 9, 4-15. (In Spanish)

20. Dávila, P.G.O. Producción de Concentrados de Hierro de Alta Ley, Haciendo Uso de Columnas de Flotación. Rev. Met. UTO 2010, 29, 19-28. (In Spanish) 
21. Azañero, O.A.; Núnez, J.P.A.; León, D.E.; Morales, V.M.; Jara, I.J.; Rendón, L.J.L. Avances en flotación columnar. Rev. Inst. Invest. Fac. Ing. Geo. Min. Met. Geogr. 2012, 6, 82-90. (In Spanish)

22. Roberia, S.D.M.A.; Magalhães, B.C.A. Importance of collector chain length in flotation of fine particles. Miner. Eng. 2018, 122, 179-184. [CrossRef]

23. Massey, W.; Harris, M.; Deglon, D. The effect of energy input on the flotation of quartz in an oscillating grid flotation cell. Miner. Eng. 2012, 36, 145-151. [CrossRef]

24. Larsen, E.; Kleiv, R. Flotation of quartz from quartz-feldspar mixtures by the HF method. Miner. Eng. 2016, 98, 49-51. [CrossRef]

25. Guilbert, J.M.; Park, C.F. The Geology of Ore Deposits, 1st ed.; Waveland Press, Inc.: New York, NY, USA, 2007; p. 985.

26. Harben, P.W.; Kuzvart, M. Industrial Minerals. A Global Geology; Metall Bulletin PLC: London, UK, 1996; pp. $168-174$.

27. U.S. Geological Survey Mineral Commodity Summaries; USGS: Reston, VA, USA, 2018; p. 200.

28. Lefond, S.J. Industrial Minerals and Rocks, 5th ed.; American Institute of Mining, Metallurgical, and Petroleum Engineers: New York, NY, USA, 1983; pp. 709-722.

29. Mexican Official Standard Number C-414-ONNCCE-1999. retrieved 03/03/17. Available online: http: //www.imcyc.com/cemento/ (accessed on 20 November 2019).

30. Norma ASTM-C-24-56 retrieved 05/03/15. Available online: https:/es.scribd.com/document/328102093/ Normas-Astm-c-resumen (accessed on 20 November 2019).

31. Ceramic DataBook; Gordon and Breach Science Publishers: Montreux, Switzerland, 1987; p. 105.

32. ASTM Standard C-24-56. Available online: https://books.google.com.mx/books?id=WRg AAAAQBAJ\&pg=PA748\&lpg=PA748\&dq=ASTM+Standard+C-24-56\&source=bl\&ots=7-Bi25hrkR\& sig=ACfU3U3HO2rBDgkGowHdS7HV5j4P39K7Ow\&hl=es\&sa=X\&ved=2ahUKEwjkzZid t3mAhUQIKwKHcSBBbcQ6AEwAHoECAgQAQ\#v=onepage\&q=ASTM\%20Standard\%20C-24-56\& $\mathrm{f}=$ false (accessed on 20 November 2019).

33. Chang, L.L.Y. Industrial Mineralogy: Materials, Processes, and Uses; Prentice-Hall: New Jersey, NJ, USA, 2001; pp. 107-113.

(C) 2020 by the authors. Licensee MDPI, Basel, Switzerland. This article is an open access article distributed under the terms and conditions of the Creative Commons Attribution (CC BY) license (http://creativecommons.org/licenses/by/4.0/). 